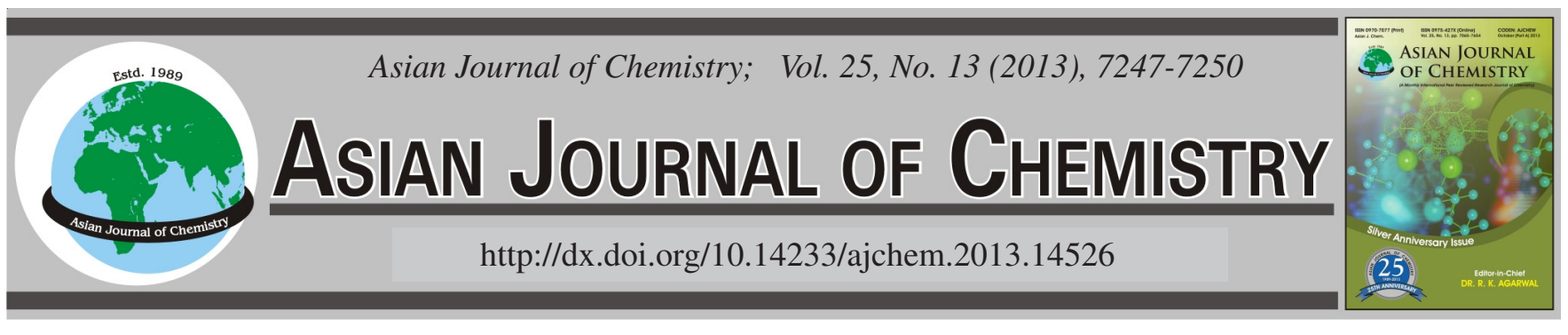

\title{
Determination of Gaseous Sulphides in the Black Liquor Pyrolysis Gas
}

\author{
Ling XiaO ${ }^{1}$, Guangzai Nong ${ }^{2}$, Bingchen Lu² ${ }^{2}$ Lije Huang ${ }^{2}$, Shiqiang $\mathrm{Li}^{2}$ and Shuangfei Wang ${ }^{2, *}$
}

${ }^{1}$ Nanning Sugar Industry Co., Ltd. Nanning 530031, P.R. China

${ }^{2}$ Institute of Light Industry and Food Engineering, Guangxi University, Nanning 530004, P.R. China

*Corresponding author: Tel/Fax: +86 771 3237097; E-mail: wangsf@ gxu.edu.cn

(Received: 5 September 2012;

Accepted: 19 June 2013)

AJC-13682

\begin{abstract}
Black liquor pyrolysis gas contains a little amount of gaseous sulphides, which need to be removed before combusting in the gas turbine in black liquor gasification combined cycle (BLGCC) or feeding into the reactor of synthesis dimethyl ether. The current investigation was carried out to find methods to determine gaseous sulphides in the black liquor pyrolysis gas. The pyrolysis gas was absorbed with benzene and then the absorption solution was analyzed by a gas chromatography and weighty. The analyzed results are: (1) the concentrations of $\mathrm{CH}_{3} \mathrm{SH}, \mathrm{CS}_{2}, \mathrm{CH}_{3} \mathrm{SCH}_{3}, \mathrm{CH}_{3} \mathrm{SSCH}_{3}, \mathrm{COS}$ and $\mathrm{H}_{2} \mathrm{~S}$ in the pyrolysis gas are 2.89, 3.88, 8.32, 2.01, 0.080 and $4.65 \mathrm{mg} / \mathrm{L}$, respectively. (2) The masses of $\mathrm{CH}_{3} \mathrm{SH}, \mathrm{CS}_{2}, \mathrm{CH}_{3} \mathrm{SCH}_{3}, \mathrm{CH}_{3} \mathrm{SSCH}_{3}, \mathrm{COS}$ and $\mathrm{H}_{2} \mathrm{~S}$ in the gasification gas account for (Wt \%) 0.168 , $0.226,0.439,0.117,0.0047$ and $0.271 \%$ of the black liquor, respectively.
\end{abstract}

Key Words: Gas chromatography, Black liquor, Gasification, Gaseous sulphides.

\section{INTRODUCTION}

In the conventional pulping process, wood was converted to pulp by the alkali cooking. After the removal of the fiber product, the remaining spent solution in deep black colour was called black liquor ${ }^{1}$. The chemical oxygen demanded value (CODCr) of black liquor is $38400-1426000 \mathrm{mg} \mathrm{L}^{-1}$, depending on different concentrations and it may be the main source of water pollutants ${ }^{2}$. On other hand, containing heat value of 13.5$15.6 \mathrm{~kJ} / \mathrm{g}$, black liquor is one of the important renewable energy resources. In most pulp mills, the black liquor was concentrated to $c a$. 55-75 \% solids and burned in Tomlinsontype recovery boilers, in which the recovery of alkali and energy was taken and at the same time, the wastewater was eliminated ${ }^{3}$.

Gasification of black liquor is a new technology for treating black liquor with high efficiency of energy and alkali recovery and with emitting less numbers of nocuous waste gases and greenhouse gas- $\mathrm{CO}_{2}{ }^{4,5}$. For example, the potential for power generation by black liquor gasification combined cycle (BLGCC) is up to 2.5 times that of the conventional systems ${ }^{6}$, having a thermal efficiency of $71.0 \%$ compared to the $50-56 \%$ efficiency of conventional recovery boilers system noted above.

For the potential advantages in energy recovery, as well as environmental benefits, the black liquor gasification technology is undergoing intense development. The first black liquor gasifier was a Swedish demonstration plant, Frövi, that processed 75-80 tons of dry solids/day between 1991-1996 built by Kvaerner $\mathrm{Chemrec}^{7}$. The first generation commercial Booster plant provided by the existing Tomlinson boiler, 300 ton solids per day was built in 1996 at Weyerhaeuser, New Bern, NC. A pilot plant for the BLGCC system was built from 1994 through 2000 at Stora Enso, Skoghall, Sweden, another 20 ton solid per day pilot BLGCC plant was built from 2004 at Kappa Kraftliner, Piteå, Sweden ${ }^{7}$.

A 10 ton solids per day oxygen-injected black liquor gasification pilot project for DME and methanol has been taken from 2004 at Kappa Kraftliner, Piteå, Sweden ${ }^{7}$. An oxygeninjected bagasse black liquor gasification pilot experiment was taken in 2006 -2008 at Guangxi University, Nanning, China, in which the thermal efficiency synthesis gas is $52.2 .2-71.2 \%$ with concentration of black liquor in range of 50-75\%, corresponding to oxygen ratio $0.4-0.6^{8}$.

Because black liquor contains 3.2-5.2 \% total sulphur ${ }^{9}$, gaseous sulphides are produced in the gas in the process of gasification $^{10-12}$. These gaseous sulphides can damage the follow-up combustion equipment and synthesis reactors and can pollute the air ${ }^{12}$. Therefore, it is necessary to develop methods to determine the sulphide compositions for finding ways to control or remove the products of gaseous sulphides in the process of gasification. The current investigation was carried out to find methods to determine the sulphides in the black liquor pyrolysis gas, including the $\mathrm{CH}_{3} \mathrm{SH}, \mathrm{CS}_{2}$, $\mathrm{CH}_{3} \mathrm{SCH}_{3}, \mathrm{CH}_{3} \mathrm{SSCH}_{3}$, COS and $\mathrm{H}_{2} \mathrm{~S}$. 


\section{EXPERIMENTAL}

The bagasse black liquor was taken from Nanning Sugar Co., Ltd. its concentration is (Wt \%) $51.0 \%$. For the dry solids of the black liquor, it contained $1.0 \%$ total sulphur (TS).

The black liquor was concentrated to $c a$. $60.0 \%$ by evaporation, was distributed on plates in a 3-5-mm-thick layer and was then dried at $103^{\circ} \mathrm{C}$ for $24 \mathrm{~h}$ to obtain dry plates. The dry plates were broken up and then were sieved to get 20-40 mesh particles.

Pyrolysis of black liquor: The pyrolysis device consisted of heating units, reaction tube and an absorber ${ }^{11}$, shown in Fig. 1. The gas controller (1) connected to a $\mathrm{N}_{2}$ storage tank and a valve (2) that connected to a tee (4), which was fixed with a temperature probe (5) and a reaction tube (9). A heater (6) was fixed outside the reaction tube that was filled with a metal grille and black liquor particles inside. Another top of reaction tube was connected to another tee, which connected to an air cooling pipe (10) that let the gas go into a benzene absorber (11). In this unit a temperature controller (3) was also installed. In another experiment, the produced gas was collected by an air collected bag, which volume was measured by a graduated cylinder filled with water to determine the volume of total produced gas.

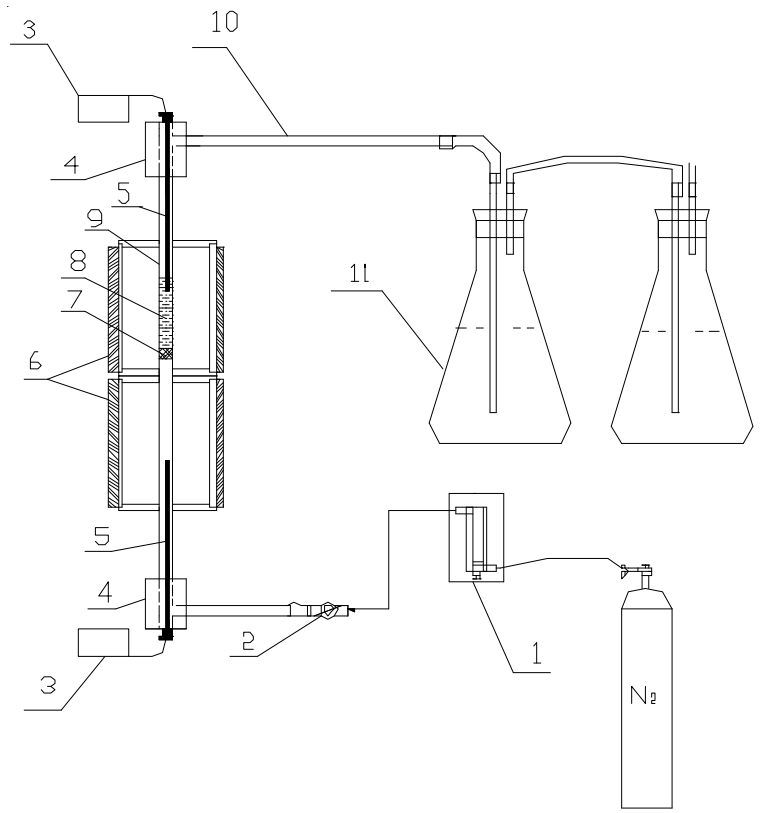

Fig. 1. Schematic diagram of experimental apparatus. 1: gas flow controller; 2: valve; 3: temperature controller; 4 : tee; 5 : temperature probe; 6 : heating units; 7: metal grille; 8: black liquor; 9: reaction tube; 10 air cooling pipe; 11: ethanol absorber

After filling the particles of black liquor into the reaction tube, turned on the valve to let the nitrogen gas join into the reaction tube to drive off the air, then turn off the valve and heated the tube, where pyrolysis reactions took place.

Analysis of elemental compositions: The elemental compositions of the bagasse black liquor were analyzed by the ICP-OES (Inductively coupled plasma Optical Emission spectrometry-Otima 5300DV) and the element analyzer (PE2400II).

Prepare the absorption solutions: The producing gas was conducted into a benzene absorber, where gaseous sulphides were absorbed by benzene solution and got the absorption solution, which would be analyzed by gas chromatography (GC).

Analysis of the absorption solutions: A gas chromatograph (Agilent Technologies 6890N) with a polyethylene glycol column (PEG, INNOWAX), a flame ionization detector (FID) and a flame photometric detector (FPD) were used for the analysis.

The masses of $\mathrm{CH}_{3} \mathrm{SH}, \mathrm{CH}_{3} \mathrm{SCH}_{3}, \mathrm{CS}_{2}$ and $\mathrm{CH}_{3} \mathrm{SSCH}_{3}$ were determined by GC with FID and the mass of COS was detected and determine by GC with FPD. The mass of $\mathrm{H}_{2} \mathrm{~S}$ was calculated by the mass of $\mathrm{CuS}$, which was produced by $\mathrm{H}_{2} \mathrm{~S}$ being absorbed with $\mathrm{CuSO}_{4}$ solution.

\section{RESULTS AND DISCUSSION}

Elemental compositions: Analyzed by the ICP-OES and the element analyzer (PE2400II). The elemental compositions of dry baggase black liquor were shown in Table-1.

Spectroscopy of absorption solution: Analyzed by the gas chromatography, the analysis spectroscopy of gaseous sulphides in the absorption solution was shown in Fig. 2. The absorption peaks of $\mathrm{CH}_{3} \mathrm{SH}, \mathrm{CS}_{2}, \mathrm{CH}_{3} \mathrm{SCH}_{3}$ and $\mathrm{CH}_{3} \mathrm{SSCH}_{3}$ were detected, located in the retention time of 2.20, 2.31, 2.40 and 2.82 min with FID. The COS was detected with FPD, located in the retention time of $0.96 \mathrm{~min}$.

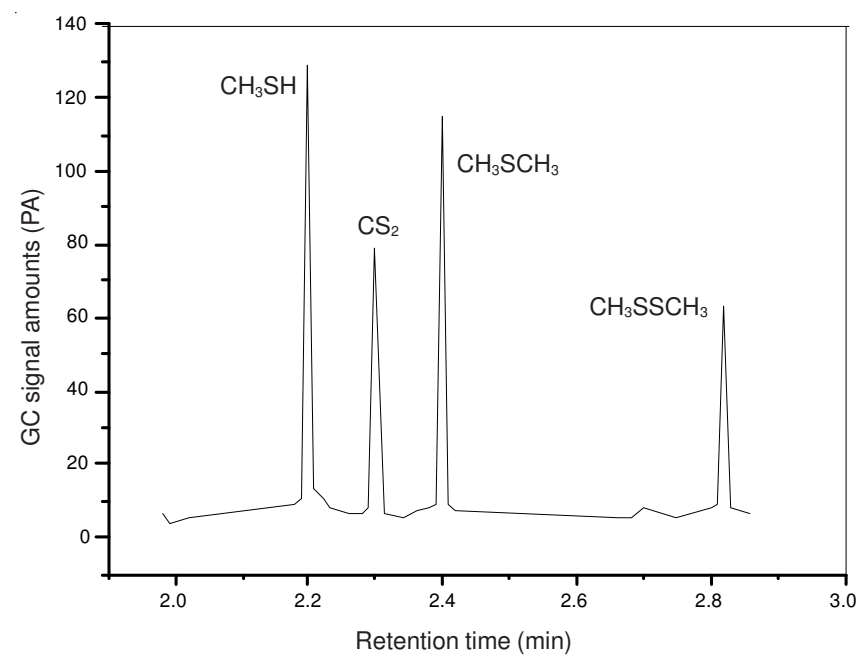

Fig. 2. Spectroscopy of gaseous sulphides in absorption solution with FID

Calculation formulae of specific gaseous sulphides: The standard curves of $\mathrm{CH}_{3} \mathrm{SH}$ were obtained by plot as shown in Fig. 3. From Fig. 3, the formula of relationship between the peak area and $\mathrm{CH}_{3} \mathrm{SH}$ concentration was:

ELEMENTAL COMPOSITIONS OF THE DRY BAGASSE BLACK LIQUOR

\begin{tabular}{lcccccccc}
\hline Elements & $\mathrm{C}$ & $\mathrm{H}$ & $\mathrm{O}$ & $\mathrm{S}$ & $\mathrm{Cl}$ & $\mathrm{Na}$ & $\mathrm{N}$ & Others \\
\hline Mass ratio (Wt \%) & 36.80 & 3.80 & 36.40 & 1.00 & 3.41 & 18.00 & 0.45 & 0.14 \\
\hline
\end{tabular}




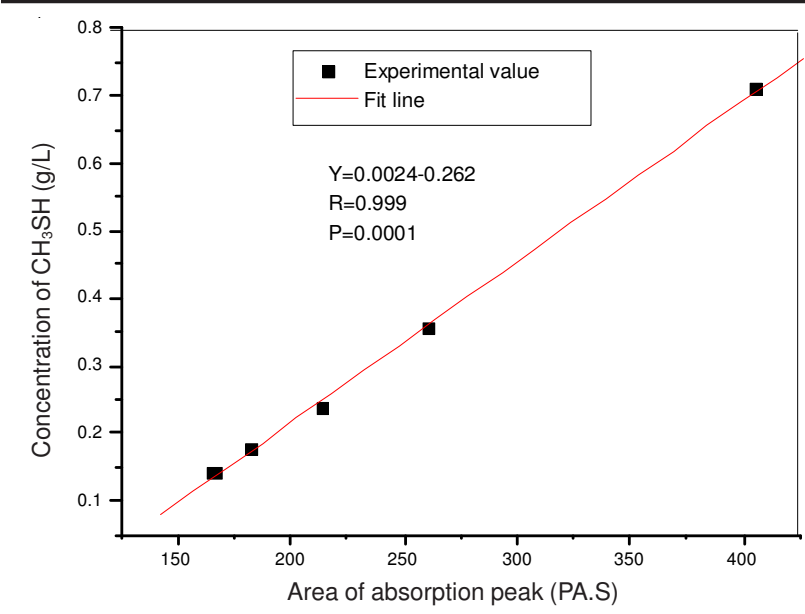

Fig. 3. Standard curves of $\mathrm{CH}_{3} \mathrm{SH}$

$$
\mathrm{c}_{\mathrm{CH}_{3} \mathrm{SH}}=0.0024 \mathrm{~A}_{\mathrm{CH}_{3} \mathrm{SH}}-0.262
$$

By the methods similar to that of $\mathrm{CH}_{3} \mathrm{SH}$, the formulas of the relationships between the peak areas and concentrations of $\mathrm{CS}_{2}, \mathrm{CH}_{3} \mathrm{SCH}_{3}, \mathrm{CH}_{3} \mathrm{SSCH}_{3}$ and $\mathrm{COS}$ were obtained, shown as formulae (2-5), respectively.

$$
\begin{aligned}
\mathrm{c}_{\mathrm{CH}_{3} \mathrm{SCH}_{3}} & =0.000877 \mathrm{~A}_{\mathrm{CH}_{3} \mathrm{SCH}_{3}}+0.0184 \\
\mathrm{c}_{\mathrm{CS}_{2}} & =0.0063 \mathrm{~A}_{\mathrm{CS}_{2}}-0.231 \\
\mathrm{c}_{\mathrm{CH}_{3} \mathrm{SSCH}_{3}} & =0.00531 \mathrm{~A}_{\mathrm{CH}_{3} \mathrm{SSCH}_{3}}-0.148 \\
\mathrm{c}_{\mathrm{COS}} & =0.00076 \mathrm{~A}_{\mathrm{COS}}-0.0015
\end{aligned}
$$

Masses and concentrations: The absorption areas, the concentrations of absorption solution, the masses of special gaseous sulphides and their concentrations were shown in Table-2. Where, concentrations of special gaseous sulphides in the absorption solution were obtained by formulae of (2-5). The masses of specific gaseous sulphides in the gas were obtained by the production of their concentrations and volume of the absorption solution. The concentrations of specific gaseous sulphides in the gas were obtained by the masses divided by the total gas volume. The volume of the absorption solution is $500 \mathrm{~mL}$ and the volume of the total produced gas is $5830 \mathrm{~mL}$, which is determined by collecting the total produced gas in an airbag.

From Table-2, the concentrations of $\mathrm{CH}_{3} \mathrm{SH}, \mathrm{CS}_{2}, \mathrm{CH}_{3} \mathrm{SCH}_{3}$, $\mathrm{CH}_{3} \mathrm{SSCH}_{3}, \mathrm{COS}$ and $\mathrm{H}_{2} \mathrm{~S}$ in the gasification gas are 2.89, 3.88, $8.32,2.01,0.080$ and $4.65 \mathrm{mg} / \mathrm{L}$, respectively. The masses of $\mathrm{CH}_{3} \mathrm{SH}, \mathrm{CS}_{2}, \mathrm{CH}_{3} \mathrm{SCH}_{3}, \mathrm{CH}_{3} \mathrm{SSCH}_{3}, \mathrm{COS}$ and $\mathrm{H}_{2} \mathrm{~S}$ in the gasification gas account for $0.168,0.226,0.439,0.117,0.0047$ and $0.271 \%$ of the black liquor, respectively.

Formation reactions of gaseous sulphides: The COS and $\mathrm{H}_{2} \mathrm{~S}$ have been detected in black liquor gasification gas in the previous studies ${ }^{13-15}$ and the formation reactions of COS and $\mathrm{H}_{2} \mathrm{~S}$ have been reported ${ }^{16-18}$, described as follows:

$$
\begin{gathered}
\mathrm{Na}_{2} \mathrm{SO}_{4}+2 \mathrm{C} \rightarrow \mathrm{Na}_{2} \mathrm{~S}+2 \mathrm{CO}_{2} \\
\mathrm{Na}_{2} \mathrm{~S}+\mathrm{CO}_{2}+\mathrm{H}_{2} \mathrm{O} \rightarrow \mathrm{Na}_{2} \mathrm{CO}_{3}+\mathrm{H}_{2} \mathrm{~S} \\
\mathrm{H}_{2} \mathrm{~S}+\mathrm{O}_{2} \rightarrow \mathrm{SO}_{2}+\mathrm{H}_{2} \\
\mathrm{Na}_{2} \mathrm{~S}+2 \mathrm{CO}_{2} \rightarrow \mathrm{Na}_{2} \mathrm{CO}_{3}+\mathrm{COS} \\
\mathrm{COS}+\mathrm{H}_{2} \rightarrow \mathrm{H}_{2} \mathrm{~S}+\mathrm{CO} \\
\mathrm{COS}+\mathrm{H}_{2} \mathrm{O} \rightarrow \mathrm{H}_{2} \mathrm{~S}+\mathrm{CO}_{2}
\end{gathered}
$$

As we know, it is first reporting about $\mathrm{CH}_{3} \mathrm{SH}, \mathrm{CS}_{2}$, $\mathrm{CH}_{3} \mathrm{SCH}_{3}$ and $\mathrm{CH}_{3} \mathrm{SSCH}_{3}$, containing in the black liquor gasification gas in this paper. Their formation reactions are supposed as follows:

$$
\begin{gathered}
\mathrm{H}_{2} \mathrm{~S}+\mathrm{CH}_{3} \mathrm{OH} \rightarrow \mathrm{CH}_{3} \mathrm{SH}+\mathrm{H}_{2} \mathrm{O} \\
\mathrm{CH}_{3} \mathrm{OH}+\mathrm{CH}_{3} \mathrm{SH} \rightarrow \mathrm{CH}_{3} \mathrm{SCH}_{3}+\mathrm{H}_{2} \mathrm{O} \\
\mathrm{CH}_{3} \mathrm{OH}+\mathrm{CH}_{3} \mathrm{SH} \rightarrow \mathrm{CH}_{3} \mathrm{OCH}_{3}+\mathrm{H}_{2} \mathrm{~S} \\
\mathrm{CH}_{3} \mathrm{SH}+\mathrm{CH}_{3} \mathrm{SH} \rightarrow \mathrm{CH}_{3} \mathrm{SCH}_{3}+\mathrm{H}_{2} \mathrm{~S} \\
\mathrm{CH}_{3} \mathrm{SH}+\mathrm{CH}_{3} \mathrm{SH} \rightarrow \mathrm{CH}_{3} \mathrm{SSCH}_{3}+\mathrm{H}_{2}
\end{gathered}
$$

Disappearance: Comparison with references, the disappearances are found as follows: Being $0.271 \%$ of black liquor, the mass of $\mathrm{H}_{2} \mathrm{~S}$ detected in these experiments is less than that of 1.6-2.0\% reported by previous workers ${ }^{15,19}$. Being $0.080 \mathrm{mg} / \mathrm{L}$ (is $80 \mathrm{ppm}$ ), the concentration of COS detected in these experiments is less than that of $150 \mathrm{ppm}$ reported in the references ${ }^{15,19}$. The masses of $\mathrm{CH}_{3} \mathrm{SH}, \mathrm{CS}_{2}, \mathrm{CH}_{3} \mathrm{SCH}_{3}$, $\mathrm{CH}_{3} \mathrm{SSCH}_{3}$ are not detected and reported in reference, but they are $0.168,0.226,0.439$ and $0.117 \%$ of black liquor in these experiments.

These disappearances might be caused by the difference in the source of black liquor and the different reacting temperatures.

In most pulp mills, the remaining black liquor contains ca. (wt \%) $5.3 \%$ of sulphur ${ }^{9,20}$. In Nanning Sugar Co. Ltd, $\mathrm{Na}_{2} \mathrm{~S}$ is banned; only $\mathrm{NaOH}$ and some chemical additives are used to cook the bagasse. So, the bagasse black liquor only contains $\mathrm{ca}$. $1.0 \%$ of sulphur. For less of sulphur, baggase black liquor produces less gaseous sulphides in gasification.

On the other hand, the $\mathrm{CH}_{3} \mathrm{SH}$ and $\mathrm{CH}_{3} \mathrm{SCH}_{3}$ can react with $\mathrm{H}_{2}$ producing $\mathrm{H}_{2} \mathrm{~S}$ at higher temperature. These reactions

\begin{tabular}{|c|c|c|c|c|c|c|}
\hline \multicolumn{7}{|c|}{$\begin{array}{c}\text { TABLE-2 } \\
\text { DATA OF DETERMINATION OF GASEOUS SULFIDES IN THE GAS (10.0 g BLACK LIQUOR) }\end{array}$} \\
\hline Compositions & $\mathrm{CH}_{3} \mathrm{SH}$ & $\mathrm{CS}_{2}$ & $\mathrm{CH}_{3} \mathrm{SCH}_{3}$ & $\mathrm{CH}_{3} \mathrm{SSCH}_{3}$ & $\mathrm{COS}$ & $\mathrm{H}_{2} \mathrm{~S}$ \\
\hline Absorption peak areas (PA.S) & 123.20 & 43.85 & 89.67 & 32.28 & 3.200 & - \\
\hline Concentrations in the absorption solution $(\mathrm{mg} / \mathrm{L})$ & 33.68 & 45.26 & 97.04 & 23.41 & 0.093 & - \\
\hline Masses (mg) & 16.84 & 22.63 & 43.90 & 11.70 & 0.047 & 27.13 \\
\hline Concentrations in gas $(\mathrm{mg} / \mathrm{L})$ & 2.89 & 3.88 & 8.32 & 2.01 & 0.080 & 4.65 \\
\hline
\end{tabular}
will increase the mass of $\mathrm{H}_{2} \mathrm{~S}$ and decrease the mass of $\mathrm{CH}_{3} \mathrm{SH}$ and $\mathrm{CH}_{3} \mathrm{SCH}_{3}{ }^{11}$.

$$
\begin{gathered}
\mathrm{CH}_{3} \mathrm{SH}+\mathrm{H}_{2} \rightarrow \mathrm{CH}_{4}+\mathrm{H}_{2} \mathrm{~S} \\
\mathrm{CH}_{3} \mathrm{SCH}_{3}+2 \mathrm{H}_{2} \rightarrow 2 \mathrm{CH}_{4}+\mathrm{H}_{2} \mathrm{~S}
\end{gathered}
$$

\section{Conclusion}

From the experiments and discussions, the following conclusions can be drawn from the experiments:

- The gaseous sulphides including $\mathrm{CH}_{3} \mathrm{SH}, \mathrm{CS}_{2}, \mathrm{CH}_{3} \mathrm{SCH}_{3}$, $\mathrm{COS}, \mathrm{CH}_{3} \mathrm{SSCH}_{3}$ and $\mathrm{H}_{2} \mathrm{~S}$ were detected in the pyrolysis gas of baggase black liquor.

- The absorption peaks of $\mathrm{CH}_{3} \mathrm{SH}, \mathrm{CS}_{2}, \mathrm{CH}_{3} \mathrm{SCH}_{3}$ and $\mathrm{CH}_{3} \mathrm{SSCH}_{3}$ were located in the retention time of 2.20, 2.31, 2.40 and 2.82 min by GC with FID. The COS was located in the retention time of 0.96 min by GC with FPD. 
- The concentrations of $\mathrm{CH}_{3} \mathrm{SH}, \mathrm{CS}_{2}, \mathrm{CH}_{3} \mathrm{SCH}_{3}, \mathrm{CH}_{3} \mathrm{SSCH}_{3}$, $\mathrm{COS}$ and $\mathrm{H}_{2} \mathrm{~S}$ in the gasification gas are 2.89, 3.88, 8.32, 2.01, 0.080 and $4.65 \mathrm{mg} / \mathrm{L}$, respectively.

- The masses of $\mathrm{CH}_{3} \mathrm{SH}, \mathrm{CS}_{2}, \mathrm{CH}_{3} \mathrm{SCH}_{3}, \mathrm{CH}_{3} \mathrm{SSCH}_{3}, \mathrm{COS}$ and $\mathrm{H}_{2} \mathrm{~S}$, in the gasification gas account for $0.168,0.226,0.439$, $0.117,0.0047$ and $0.271 \%$ of the black liquor, respectively.

\section{ACKNOWLEDGEMENTS}

The authors express their great appreciation to the Guangxi Science Research and Technology Development project (code: 10100025) for financial support.

\section{REFERENCES}

1. Q. Wang, K.F. Chen, J. Li, S.S. Liu and Z.J. Wang, Biol. Resources, 5, 2681 (2010)

2. C.Y. Yang, Y. Niu, H.J. Su, Z. Wang, F. Tao, X. Wang, H.Z. Tang, C.Q. Ma and P. Xu, Bioresour. Technol., 101, 1737 (2010).

3. K. Pettersson and S. Harvey, Energy, 37, 136 (2012).

4. K. Möllersten, J. Yan and M. Westermark, Energy, 28, 691 (2003).

5. J.M. Joelsson and L. Gustavsson, Resour. Conserv. Recy., 52, 747 (2008).
6. N. Berglin and T. Berntsson, Appl. Therm. Eng., 18, 947 (1998).

7. I. Landälv, Advance in Black Liquor Gasification, European Conference on Biorefinery Research, Helsinki, 19 and 20, October (2006).

8. G.Z. Nong, X.S. Li and S.F. Wang, China Pulp Paper, 27, 37 (2008)

9. M. Cardoso, É.D. De Oliveira and M.L. Passos, Fuel, 88, 756 (2009).

10. G.Z. Nong, J.J. Mu, X.L. Zhang and S.F. Wang, China Pulp Paper Ind, 31, 16 (2010)

11. G.Z. Nong, S.F. Wang, J.J. Mu and X.L. Zhang, Asian J. Chem., 24, 3118 (2012).

12. G.Z. Nong, L.J. Huang, B.C. Lu, S.Q. Li, H.T. Mo and S.F. Wang, Asian J. Chem., 24, 5469 (2012).

13. M. Naqvi, J. Yan and E. Dahlquist, Appl. Energ., 90, 24 (2012).

14. M. Naqvi, J. Yan and E. Dahlquist, Bioresour. Technol., 110, 637 (2012).

15. P. Carlsson, H. Wiinikka, M. Marklund, C. Grönberg, E. Pettersson, M. Lidman and R. Gebart, Fuel, 89, 4025 (2010).

16. H.J. Huang and S. Ramaswamy, Biol. Resour., 6, 3210 (2010).

17. M. Naqvi, J.Y. Yan and E. Dahlquist, Appl. Energ., 97, 49 (2012).

18. H. Wiinikka, P. Carlsson, M. Marklund, C. Grönberg, E. Pettersson, M. Lidman and R. Gebart, Fuel, 93, 117 (2012).

19. O. Öhrman, C. Häggström, H. Wiinikka, J. Hedlund and R. Gebart, Fuel, 102, 179 (2012).

20. H. Wiinikka, P. Carlsson, F. Granberg, J. Löfström, M. Marklund, R. Tegman, M. Lindblom and R. Gebart, Fuel, 89, 2583 (2010). 